\title{
GOOD CORPORATE GOVERNANCE DAN KINERJA MAQASID SYARIAH BANK SYARIAH DI INDONESIA
}

\author{
Muamar Nur Kholid \\ Fakultas Ekonomi Universitas Islam Indonesia \\ e-mail: Muamar.nk@uii.ac.id \\ Arief Bachtiar \\ Fakultas Ekonomi Universitas Islam Indonesia \\ e-mail: arief.bachtiar@uii.ac.id
}

\begin{abstract}
This study aims to examine the influence of good corporate governance, namely board of commissioner, shariah supervisory board, and audit committee to maqasid shariah performance of Islamic bank. This study based on agency theory. This study take sampel from 7 Islamic bank in Indonesia, 2010-2014. The method of analysis of this research used multi regression. The results of this study show that, (1) size of board of commissioner had positive significant to maqasid shariah performance of Islamic bank, (2) size of audit committee had negative significant to maqasid shariah performance of Islamic bank, and (3) shariah supervisory board (DPS) had no significant influence to maqasid shariah performance of Islamic bank.
\end{abstract}

Keywords : corporate governance, agency theory, maqasid shariah performance of Islamic bank http://dx.doi.org/10.20885/jaai.vol19.iss2.art4

\begin{abstract}
Abstrak
Penelitian ini bertujuan untuk mendapatkan bukti empiris mengenai pengaruh good corporate governance yang diproksikan dengan jumlah dewan komisaris, dewan pengawas syariah dan komite audit terhadap kinerja maqasid syariah bank syariah di Indonesia. Penelitian ini didasarkan pada teori agensi dengan menggunakan sampel 7 bank syariah di Indonesia dari tahun 2010-2014 dan menggunakan metode analisis regresi berganda. Hasil penelitian ini menunjukkan bahwa (1) jumlah dewan komisaris memiliki pengaruh positif signifikan terhadap kinerja maqasid syariah bank syariah, (2) jumlah komite audit berpegaruh negatif signifikan terhadap kinerja maqasid syariah bank syariah, (3) jumlah dewan pengawas syariah tidak berpengaruh terhadap kinerja maqasid syariah bank syariah di Indonesia.
\end{abstract}

Kata kunci : good corporate governance, teori agensi, kinerja maqasid syariah bank syariah

\section{PENDAHULUAN}

Perkembangan kinerja bank syariah yang hanya dinilai dari pertumbuhan aset dan market share, menjadikannya tidak berbeda dengan bank konvensional sebagai organisasi yang berorientasi pada laba (Reni, Muklis dan Cholisni 2014). Menurut Mohammed, Razak dan Taib (2008), tujuan bank syariah akan tepat jika diturunkan dari tujuan syariah (maqasid syariah). Penilaian kinerja bank syariah tidak hanya dinilai dari profitabilitasnya saja namun juga kesesuaian dengan syariah Islam (Reni, Muklis dan Cholisni 2014). Operasional bank syariah harus sesuai dengan syariah Islam karena syariah Islam memiliki tujuan syariah (maqasid syariah) sehingga tujuan bank syariah akan tepat jika diturunkan dari maqasid syariah, karenanya pengukuran kinerja untuk mengetahui ketercapaiannya terhadap tujuan akan tepat jika pengukurannya berbasiskan pada maqasid syariah.

Bank syariah memiliki peran menghimpun dana dari nasabah yang kelebihan uang (pendanaan) dan menyalurkan uang kepada nasabah yang membutuhkan uang (pembiayaan). Penjelasan mengenai hubungan 
antara nasabah dan bank dapat dijelaskan dengan menggunakan dasar teori agensi. Menurut teori agensi, dalam perusahaan terdapat pemisahan antara pemilik dana dengan pengelola dana (bank), dengan kata lain pemilik dana mempercayakan dananya kepada bank syariah untuk dilakukan pengelolaan atas dana tersebut. Pemisahan ini berakibat pada terjadinya kemungkinan masalah agensi. Adanya kemungkinan masalah agensi tersebut mendorong perlunya good corporate governance. Good corporate governance kaitannya dengan perbankan merupakan suatu sistem pengelolaan yang dirancang untuk meningkatkan kinerja bank, melindungi kepentingan stakeholder, dan meningkatkan kepatuhan terhadap perundang-undangan serta nilai-nilai etika yang berlaku secara umum (Faozan 2013). Berkaitan dengan kemungkinan masalah agensi yaitu bank tidak menjalankan operasional usahanya sesuai syariah Islam, maka dibutuhkan mekanisme good corporate governance dengan pembentukan Dewan Pengawas Syariah (DPS).

Mekanisme good corporate governance yang secara tidak langsung juga memiliki peran dalam pengawasan kepatuhan bank syariah terhadap syariah Islam adalah dewan komisaris dan komite audit. Menurut Peraturan Bank Indonesia No.11/33/PBI/2009 tentang pelaksanaan good corporate governance pada bank umum syariah dan unit usaha syariah, dewan komisaris dan komite audit memiliki wewenang untuk melakukan evaluasi terhadap pelaksanaan tindak lanjut direksi bank syariah terhadap temuan dewan pengawas syariah. Dengan adanya dewan komisaris dan komite audit ini bank syariah mematuhi segenap peraturan-peraturan yang ada, sehingga masalah agensi dapat berkurang yang nantinya diharapkan dapat meningkatkan kinerja bank syariah itu sendiri.

Beberapa penelitian terkait good corporate governance yang dikaitkan dengan kinerja bank dapat ditemukan pada beberapa penelitian sebelumnya. Penelitian Mollah dan Zaman (2015) yang meneliti 147 bank syariah di berbagai negara menemukan bahwa jumlah dewan pengawas syariah (DPS) berpengaruh positif signifikan terhadap ROIAE. Penelitian Muttakin dan Ullah (2012) yang meneliti 30 bank di Bangladesh dari tahun 2005 sampai 2010 menemukan bahwa jumlah board of director berpengaruh positif terhadap ROA. Penelitian Hoque, Islam dan Ahmed (2012) yang meneliti 25 bank di Bangladesh 20032011 menemukan jumlah board of director dan jumlah rapat komite audit berpengaruh positif signifikan terhadap ROA. Penelitian At Baidhani (2013) yang mengukur kinerja bank dengan menggunakan ROE, ROA dan profit margin pada bank konvensional dan bank syariah Islam di Yaman, menemukan bahwa jumlah anggota komite audit berpengaruh positif signifikan terhadap ROE. Penelitian Sam'ani (2008) yang meneliti bankbank yang terdaftar di Bursa Efek Indonesia menemukan bahwa jumlah anggota komite audit berpengaruh positif signifikan terhadap ROA. Penelitian Syam dan Najda (2012) yang meneliti kualitas good corporate governance pada Bank Umum Syariah yang diukur dengan indikator-indikator yang telah ditetapkan oleh bank syariah Indonesia, menemukan bahwa kualitas good corporate governance tidak mempengaruhi kinerja bank syariah yang diukur dengan ROA.

Beberapa penelitian terdahulu yang sudah dipaparkan di atas baik bank Islam maupun bank konvensional, keseluruhannya menggunakan ukuran profitabilitas berupa ROA, ROE, profit margin ataupun Tobins-Q, yang artinya bahwa peneliti-peneliti sebelumnya tidak membedakan ukuran kinerja antara bank syariah dan bank konvensional. Penelitian ini akan fokus terhadap pengukuran kinerja bank umum syariah yang mengukur kinerja bank tidak hanya dengan ukuran profitabilitas melainkan juga akan diukur dengan kinerja maqasid syariah bank syariah yang dikembangkan oleh Mohammed, Razak dan Taib (2008). Penelitian ini juga hanya fokus pada mekanisme good corporate governance pada struktur internal bank syariah yang terdiri dari dewan komisaris, dewan pengawas syariah dan komite audit.

Tujuan dari penelitian ini adalah untuk menguji secara empiris pengaruh good corpo- 
rate governance yang diproksikan dengan jumlah anggota dewan komisaris, jumlah dewan pengawas syariah, dan jumlah anggota komite audit terhadap kinerja maqasid syariah bank syariah.

\section{TINJAUAN PUSTAKA DAN PERUMUSAN HIPOTESIS}

\section{Teori Agensi}

Teori agensi menjelaskan hubungan antra prinsipal dan agen. Prinsipal adalah pihak yang memberikan mandat kepada agen untuk bertindak atas nama prinsipal, sementara agen merupakan pihak yang diberikan mandat untuk bertindak atas nama prinsipal. Hal tersebut akan mensyaratkan agen untuk bertanggung jawab atas setiap tindakannya kepada prinsipal. Teori agensi menghendaki adanya pemisahan antara prinsipal dan agen, hal tersebut memicu adanya asymetric information dimana agen memiliki informasi yang lebih baik mengenai organisasi dari pada prinsipal. Adanya asymetric information dapat memicu masalah agensi baik itu berupa moral hazard dan/atau adverese selection (Jensen dan meckling 1976). Terkait dengan kemungkinan munculnya masalah agensi, menurut Jensen dan Meckling (1976) akan menimbulkan biaya keagenan untuk menekan masalah agensi tersebut yang terdiri dari (1) biaya monitoring, (2) bonding expediture, dan (3) residual loss.

\section{Kinerja Maqasid syariah Bank Syariah}

Segala aktivitas seorang muslim harus didasarkan pada syariah Islam tidak terkecuali kegiatan ekonomi. Bagi masyarakat muslim, bank yang merupakan komponen vital dari kegiatan ekonomi harus berlandaskan pada syariah Islam, yang sering disebut sebagai bank syariah atau bank Islam. Syariah Islam memiliki tujuan yang sering disebut sebagai maqasid syariah. Menurut Mohammed, Razak dan Taib (2008), tujuan Bank Syariah akan tepat jika diturunkan dari tujuan syariah (maqasid syariah). Hal ini dikarenakan tujuan dari bank Islam tidak hanya memaksimalkan laba, namun juga memiliki peran di bidang sosial. Oleh karena tujuannya tidak hanya memaksimalkan laba, maka pengukuran kinerja dari bank syariah menjadi lebih kompleks.

Pengukuran kinerja bank syariah berbasis maqasid syariah merupakan proses untuk menentukan apakah bank syariah dapat mencapai tujuan bank syariah yang diturunkan dari maqasid syariah. Pengukuran kinerja mempunyai hubungan langsung dengan dengan tujuannya, sehingga indikator-indikator pencapaian kinerjanya akan diturunkan dari tujuantujuan tersebut. Mohammed, Razak dan Taib (2008) menggunakan klasifikasi maqasid syariah menurut Abu Zaharah (1997) yaitu: (1) Tahdhib al-Fard (mendidik individu); (2) Iqamah Al-adl (menegakkan keadilan), dan; (3) Jaib al-Maslahah (meningkatkan kesejahteraan).

Pengembangan pengukuran kinerja yang dilakukan Mohammed, Razak dan Taib (2008) menggunakan metode dari Uma Sekaran (2000). Metode tersebut dibangun dengan mengidentifikasi dimensi-dimensi dari setiap tujuan syariah, yang selanjutnya dari dimensi-dimensi tersebut ditentukan elemenelemen yang menunjukkan ketercapaian dari dimensi tersebut.

\section{Dewan Komisaris dan Kinerja Maqasid syariah Bank Syariah}

Dewan komisaris memiliki tugas untuk memberikan saran dan melakukan pengawasan terhadap tugas dan tanggung jawab direksi terkait dengan opersional bank. Dewan komisaris juga memiliki kewajiban memastikan bahwa direksi telah menindaklanjuti temuan maupun rekomendasi yang diberikan oleh dewan pengawas syariah terkait kepatuhan operasional bank syariah terhadap syariah Islam. Dewan komisaris dalam penelitian ini diukur dengan jumlah anggota dewan komisaris. Menurut Lehn, Patro dan Zhao (2004) ukuran board of director (komisaris) yang lebih besar memungkinkan perolehan informasi yang lebih banyak terkait dengan hal-hal yang mempengaruhi perusahaan seperti market, teknologi, peraturan-peraturan terkait dan lainlain yang akan sangat bermanfaat bagi pelaksanaan monitoring dan pemberian nasihat oleh 
dewan komisaris. Hal tersebut menandakan bahwa jumlah anggota dewan komisaris yang besar mampu melakukan pengawasan yang lebih baik, sehingga masalah agensi dapat ditekan dan tujuan yang ingin dicapai oleh bank dapat tercapai. Namun begitu ukuran board of director yang besar kurang ekfektif untuk melakukan koordinasi, dan membutuhkan biaya yang tinggi untuk melakukan koordinasi (James dan Joseph 2015).

Penelitian Muttakin dan Ullah (2012) yang meneliti 30 bank di Bangladesh, penelitian Adams dan Mehran (2012) yang meneliti 35 Bank Holding Company dan penelitian Hoque, Islam dan Ahmed (2012) yang meneliti 25 bank di Bangladesh 2003-2011 menemukan bahwa jumlah board of director (komisaris) mempengaruhi kinerja keuangan bank. Berdasarkan uraian di atas dirumuskan hipotesis berikut:

H1: Jumlah anggota dewan komisaris berpengaruh positif terhadap kinerja maqasid syariah bank syariah.

\section{Dewan Pengawas Syariah dan Kinerja Maqasid syariah Bank Syariah}

Masalah agensi yang disebabkan karena asymetric information antara pemilik dana dengan manajemen dapat memicu bank syariah untuk tidak bertindak sesuai dengan kontrak yang telah disepakati antara pemilik dana dengan bank syariah. Mekanisme dewan pengawas syariah dapat meningkatkan kinerja maqasid syariah bank syariah karena adanya dewan pengawas syariah yang baik, memilki pengawasan yang baik sehingga diharapkan bank syariah dapat mematuhi ketentuanketentuan syariah yang telah disepakati, dan manajemen bank syariah tidak memanfaatkan bargaining power yang dimiliki untuk mengelabuhi nasabah dan memperkaya diri mereka sendiri.

Menurut Muttakin dan Ullah (2012), semakin banyak anggota dewan pengawas syariah akan mendorong kinerja yang lebih baik karena dewan lebih memiliki pengalaman, kepakaran, keahlian, dan jaringan profesional serta sosial yang lebih baik. Semakin banyak anggota dewan pengawas syariah maka pengawasan yang dilakukan akan lebih baik sehingga tingkat kepatuhan syariah bank syariah menjadi lebih baik. Adanya pengawasan yang baik akan menurunkan masalah agensi yang dilakukan oleh manajemen bank syariah, dengan berkurangnya masalah agensi maka kinerja maqasid syariah bank syariahnya menjadi lebih baik.

Keberadaan dewan pengawas syariah adalah untuk memonitoring ketaatan bank syariah terhadap syariah Islam sehingga diharapkan dapat menekan masalah agensi yang pada akhirnya akan mengakibatkan kinerja bank syariah menjadi lebih baik. Penelitian Mollah dan Zaman (2015) menemukan bahwa ukuran dewan pengawas syariah berpengaruh positif terhadap kinerja keuangan bank syariah. Berdasarkan urain di atas, dirumuskan hipotesis berikut:

$\mathrm{H} 2$ : Jumlah anggota dewan pengawas syariah berpengaruh positif terhadap kinerja maqasid syariah bank syariah.

\section{Komite Audit dan Kinerja Maqasid syariah Bank Syariah}

Tugas pokok dari komite audit menurut Peraturan Bank Indonesia No.11/33/PBI/2009 pasal 42 ayat 1 adalah melakukan evaluasi atas pelaksanaan audit internal dalam rangka menilai kecukupan pengendalian internal dan kecukupan proses pelaporan keuangan. Selain itu pada ayat 2 juga disebutkan bahwa komite audit juga memiliki tugas melakukan evaluasi terhadap pelaksanaan tindak lanjut oleh direksi atas hasil temuan dan/atau rekomendasi dari hasil pengawasan dewan pengawas syariah. Hal tersebut menandakan bahwa komite audit secara tidak langsung juga memiliki wewenang untuk mengawasi kepatuhan bank syariah terhadap syariah Islam. Menurut At Matari et al. (2012), komite audit juga melakukan monitoring terhadap pengendalian internal perusahaan dan menyediakan informasi yang reliable (terpercaya) bagi stakeholder. Informasi yang reliable dan transparansi dalam laporan keuangan ini penting karena hal tersebut merupakan salah satu usaha untuk dapat mencapai tujuan keadilan yang merupakan salah satu tujuan dari 
maqasid syariah. Oleh karena itu diharapkan dengan adanya komite audit maka tingkat transparansi dan keandalan laporan keuangan menjadi lebih baik dan tercipta keadilan sehingga hal tersebut dapat meningkatkan kinerja maqasid syariah bank syariah.

Menurut Bouaziz (2012), perusahaan dengan jumlah anggota komite audit yang lebih banyak akan menyediakan sumber daya yang lebih banyak pula untuk melakukan pengawasan terhadap proses pelaporan akuntansi dan keuangan. Sementara itu Ał Matari et al. (2012) menyatakan bahwa jumlah anggota komite audit yang lebih banyak dapat meningkatkan pengetahuan yang digunakan untuk melakukan pengawasan. Penelitian At Baidhani (2013) yang meneliti bank konvensional dan bank syariah Islam di Yaman dan Sam'ani (2008) yang meneliti bank yang terdaftar di Bursa Efek Indonesia menemukan bahwa jumlah anggota komite audit berpengaruh positif signifikan terhadap kinerja keuangan bank. Berdasar urain di atas, dirumuskan hipotesis berikut:

H4: Jumlah anggota komite audit berpengaruh positif terhadap kinerja maqasid syariah bank syariah

\section{METODA PENELITIAN}

\section{Populasi dan Sampel}

Populasi dalam penelitian ini adalah seluruh Bank Umum Syariah di Indonesia. Sampel dipilih dengan metode purposive sampling dengan kriteria sebagai berikut (1) Menyajikan laporan keuangan lengkap di website masingmasing bank syariah selama tahun 2010 sampai 2014, (2) Menyajikan laporan good corporate governance di website masing-masing bank syariah selama tahun 2010 sampai 2014. Berdasarkan kriteria tersebut terpilih 7 bank umum syariah yang memenuhi kriteria dengan periode pengamatan selama 5 tahun maka total sampel adalah 35. Proses pemilihan sampel disajikan pada Tabel 1 .

\section{Jenis dan Sumber Data}

Jenis data dalam penelitian ini adalah data sekunder, berupa laporan tahunan dan laporan good corporate governance. Sumber data dalam penelitian ini berasal dari website bank syariah terkait.

Tabel 1: Proses pemilihan sampel

\begin{tabular}{lc}
\multicolumn{1}{c}{ Keterangan } & $\begin{array}{c}\text { Jumlah } \\
\text { Bank }\end{array}$ \\
\hline Jumlah Bank Umum Syariah & 11 \\
Tidak menyajikan laporan tahunan & 4 \\
$\begin{array}{l}\text { lengkap selama 5 tahun berturut-turut } \\
\text { Tidak menerbitkan laporan GCG }\end{array}$ & 3 \\
selama 5 tahun berturut-turut & 7 \\
Jumlah sampel per tahun &
\end{tabular}

Sumber : Data diolah, 2015

\section{Definisi Operasional dan Pengukuran Variabel}

Variabel penelitian ini terdiri dari variabel dependen dan independen. Variabel dependen dalam penelitian ini adalah kinerja maqasid syariah bank syariah, sedangkan variabel independennya terdiri dari dewan komisaris, dewan pengawas syariah dan komite audit.

Pengukuran kinerja merupakan proses menentukan apakah organisasi mencapai tujuannya (Rouse dan Puterill 2003). Kinerja maqasid syariah bank syariah dapat didefinisikan sebagai tingkat bank syariah dalam mencapai tujuan syariah Islam (maqasid syariah). Kinerja maqasid syariah bank syariah pada penelitian ini mengambil pengukuran yang dikembangkan oleh Mohammed, Razak dan Taib (2008). Adapun langkah-langkah dalam pengukuran kinerja maqasid syariah adalah sebagai berikut:

a. Mengukur rasio-rasio yang mewakili setiap elemen dari tujuan bank berbasis maqasid syariah. Elemen-elemen dan rasio tersebut disajikan dalam Tabel 2.

b. Mengalikan hasil pengukuran rasio dengan bobot masing-masing elemen. Bobot masing-masing elemen dapat dilihat dalam Tabel 3.

c. Hasil dari langkah b dijumlahkan sesuai dengan klasifikasi elemen menurut tujuan.

d. Hasil dari langkah c dikalikan dengan bobot menurut tujuan.

e. Menjumlahkan seluruh hasil dari langkah d. 
Tabel 2 : Operasionalisasi Rasio Pengukur Kinerja

\begin{tabular}{|c|c|c|c|}
\hline $\begin{array}{l}\text { Konsep } \\
\text { (tujuan) }\end{array}$ & Dimesi & Elemen & Rasio Kinerja \\
\hline \multirow{4}{*}{$\begin{array}{l}\text { Mendidik } \\
\text { Individu }\end{array}$} & Kemajuan & $\begin{array}{l}\text { Bantuan } \\
\text { Pendidikan }\end{array}$ & R1. Bantuan pendidikan / total biaya \\
\hline & Pengetahuan & Penelitian & R2. Biaya penelitian/total biaya \\
\hline & $\begin{array}{l}\text { Peningkatan Keahlian } \\
\text { Meningkatkan }\end{array}$ & Pelatihan & R3. Biaya pelatihan/total biaya \\
\hline & $\begin{array}{l}\text { Kesadaran akan Bank } \\
\text { syariah Islam }\end{array}$ & Publikasi & R4. Biaya promosi/total biaya \\
\hline \multirow{3}{*}{$\begin{array}{l}\text { Membangun } \\
\text { Keadilan }\end{array}$} & Kontrak yang Adil & Fair Return & R5. Laba bersih/total pendapatan \\
\hline & $\begin{array}{l}\text { Jasa dan Produk yang } \\
\text { Teriangkau }\end{array}$ & $\begin{array}{l}\text { Harga yang } \\
\text { teriangkau }\end{array}$ & $\begin{array}{l}\text { R6. Total pembiayaan \& piutang bersih/ } \\
\text { Total pembiayaan \& piutang }\end{array}$ \\
\hline & $\begin{array}{l}\text { Menghilangkan } \\
\text { Ketidakadilan }\end{array}$ & $\begin{array}{l}\text { Produk bebas } \\
\text { bunga }\end{array}$ & $\begin{array}{l}\text { R7. Pendapatan bebas bunga/total pen- } \\
\text { dapatan }\end{array}$ \\
\hline \multirow{3}{*}{$\begin{array}{l}\text { Kepentingan } \\
\text { Publik }\end{array}$} & Profitabilitas & Rasio laba & R8. Laba bersih/total asset \\
\hline & $\begin{array}{l}\text { Distribusi Pendapatan } \\
\text { dan Kesesjahteraan }\end{array}$ & $\begin{array}{l}\text { Pendapatan } \\
\text { individu }\end{array}$ & R9. Zakat/ laba bersih \\
\hline & $\begin{array}{l}\text { Investaisi dalam } \\
\text { Sektor Riil }\end{array}$ & $\begin{array}{l}\text { Rasio investasi } \\
\text { di sektor riil }\end{array}$ & R10. Total investasi sektor riil/ total asset \\
\hline
\end{tabular}

Tabel 3 : Bobot Masing-Masing Tujuan dan Elemen

\begin{tabular}{lclc}
\hline \multicolumn{1}{c}{ Tujuan } & Bobot Tujuan (\%) & \multicolumn{1}{c}{ Elemen } & Bobot Elemen (\%) \\
\hline \multirow{3}{*}{ T1.Pendidikan } & & E1. Bantuan Pendidikan & 24 \\
& \multirow{3}{*}{30} & E2. Penelitian & 27 \\
& & E3. Training & 26 \\
& & E4. Publikasi & 23 \\
& & Total & $\mathbf{1 0 0}$ \\
T2. Keadilan & \multirow{3}{*}{41} & E5. Fair Return & 30 \\
& & E6. Fair Price & 32 \\
& & E7. Produk bebas bunga & 38 \\
& & Total & $\mathbf{1 0 0}$ \\
T3.Kesejahteraan & & E8. Rasio laba & 33 \\
& \multirow{2}{*}{29} & E9. Transfer Pendapatan & 30 \\
& & E10. Rasio Investasi sektor riil & 37 \\
& & Total & $\mathbf{1 0 0}$ \\
\hline
\end{tabular}

\section{Total} 100

Sumber : Mohammed, Razak dan Taib (2008)

Menurut Undang-undang No.40 tahun 2007 tentang perseroan terbatas menyatakan bahwa dewan komisaris merupakan organ perseroan yang bertugas melakukan pengawasan secara umum dan/atau khusus sesuai dengan anggaran dasar serta memberikan nasihat kepada direksi. Dewan komisaris dalam penelitian ini diukur dari jumlah anggota dewan komisaris.

Menurut Peraturan Bank Indonesia No.11/33/PBI/2009 tentang pelaksanaan good corporate governance pada bank umum syariah dan unit usaha syariah, Dewan pengawas syariah adalah dewan yang bertugas memberikan saran dan nasihat kepada direksi serta mengawasi kegiatan bank agar sesuai dengan prinsip syariah. Dewan Pengawas Syariah dalam penelitian ini diukur dengan jumlah anggota dewan pegawas syariah.

Komite audit adalah komite yang dibentuk oleh direksi atas persetujuan dewan komisaris yang memiliki tanggung jawab menilai kecukupan pengendalian internal, kecukupan proses pelaporan keuangan dan 
mengevaluasi tindak lanjut direksi atas temuan audit dan/atau rekomendasi dari Bank Indonesia, auditor internal, dewan pengawas syariah dan auditor ekstenal. Komite audit dalam penelitian ini diukur dengan jumlah anggota komite audit.

\section{Teknik Analisis Data}

Teknik analisis data dalam penelitian ini menggunakan statistik deskriptif, uji asumsi klasik yang meliputi uji normalitas, uji multikolinearitas, dan uji heterodeksitas, serta pengujian hipotesis menggunakan regresi berganda. Model persamaan regresi untuk menguji hipotesis adalah sebagai berikut:

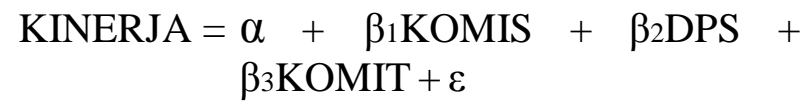

Keterangan :

KINERJA = Kinerja maqasid syariah bank syariah

KOMIS = Jumlah anggota dewan komisaris

DPS = Jumlah anggota dewan pengawas syariah

KOMIT = Jumlah anggota komite audit

$$
\begin{array}{ll}
\alpha & =\text { Konstanta } \\
\beta & =\text { Koefisien Regresi } \\
\varepsilon & =\text { Error term }
\end{array}
$$

\section{HASIL DAN PEMBAHASAN}

\section{Statistik Deskriptif dan Uji Asumsi Klasik}

Statistik deskriptif untuk masing-masing variabel, baik variabel dependen maupun independen disajikan pada Tabel 4. Hasil uji asumsi klasik masing-masing disajikan pada Tabel 5 untuk uji normalitas dengan kolmogorov smirnov, Tabel 6 untuk uji multikolinearitas, dan Tabel 7 untuk uji heterodeksitas. Berdasarkan Tabel 4 dapat dilihat bahwa kinerja maqasid syariah bank syariah di Indonesia paling baik sebesar 36,09 dan paling rendah 25,99. Dilihat dari variable independen data maksimum paling besar dimiliki oleh jumlah anggota komisaris sebanyak 6 orang sementara paling rendah jumlah dewan pengawas syariah sebanyak 3 orang. Sementara rata-rata jumlah anggota untuk dewan pengawas syariah, komisaris dan komite audit masing-masing 2,48, 4,17 dan 3,40.

Tabel 4: Statistik Deskriptif Variabel Penelitian

\begin{tabular}{lccccc}
\hline \multicolumn{1}{c}{ Nama Variabel } & $\begin{array}{c}\text { Jumlah } \\
\text { Data }\end{array}$ & $\begin{array}{c}\text { Data } \\
\text { Minimum }\end{array}$ & $\begin{array}{c}\text { Data } \\
\text { Maksimum }\end{array}$ & Rata-rata & $\begin{array}{c}\text { Std. } \\
\text { Deviation }\end{array}$ \\
\hline Kinerja maqasid syariah bank & 35 & 25,99 & 36,09 & 31,62 & 1,83 \\
syariah & 35 & 2,00 & 3,00 & 2,48 & 0,55 \\
Jumlah DPS & 35 & 3,00 & 6,00 & 4,17 & 1,43 \\
Jumlah Komisaris & 35 & 2,00 & 5,00 & 3,40 & 0,81 \\
Jumlah anggota komite audit & & &
\end{tabular}

Sumber : Data diolah, 2015

Tabel 5: Hasil Uji Kolmogorov-Smirnov

\begin{tabular}{llr}
\hline & & \multicolumn{2}{c}{ Unstandardized } \\
Residual
\end{tabular}

Sumber : Data diolah, 2015. 
Tabel 6: Hasil Uji Multikolinearitas

\begin{tabular}{lccc}
\hline & Nama Variabel & Tolerance & VIF \\
\hline DPS & .742 & 1.348 \\
KOMIS & .620 & 1.612 \\
KOMIT & .796 & 1.256 \\
\hline
\end{tabular}

Sumber : Data diolah, 2015.

Tabel 8: Hasil Uji Heterodeksitas

\begin{tabular}{lrrrrr}
\hline \multirow{2}{*}{ Model } & \multicolumn{2}{c}{ Unstandardized } & \multicolumn{2}{c}{$\begin{array}{c}\text { Standardized } \\
\text { Coefficients }\end{array}$} & \multicolumn{2}{c}{ Coefficients } & \multirow{2}{*}{ t } & \multirow{2}{*}{ Sig. } \\
\cline { 2 - 4 } & \multicolumn{1}{c}{ B } & Std. Error & Beta & & \\
\hline (Constant) & 2,258 &, 652 & & 3,461 &, 002 \\
DPS &,- 494 &, 252 &,- 389 & $-1,963$ &, 059 \\
KOMIT &, 008 &, 160 &, 010 &, 049 &, 961 \\
KOMIS &, 023 &, 097 &, 054 &, 241 &, 811 \\
\hline
\end{tabular}

Sumber : Data diolah, 2015.

Berdasarkan Tabel 5, 6 dan 7, maka dapat disimpulkan bahwa data telah memenuhi uji asumsi klasik yang terdiri dari uji normalitas data, uji multikoliniearitas dan uji heterokedastisitas. Oleh karena itu pengujian hipotesis dengan menggunakan analisis regresi berganda dapat dilakukan.

\section{Pengujian Hipotesis dan Pembahasan}

Hasil pengujian hipotesis dengan menggunakan analisis regresi berganda disajikan pada Tabel 8. Berdasarkan hasil analisis regresi berganda pada Tabel 8, menunjukkan bahwa jumlah anggota dewan komisaris (KOMIS) berpengaruh positif signifikan terhadap kinerja maqasid syariah bank syariah pada tingkat signifikan 5\%. Hasil ini sejalan dengan penelitian Adams dan Mehran (2012), Muttakin dan Ullah (2012), dan Hoque, Islam dan Ahmed (2012) yang mengukur kinerja bank dengan profitabilitas. Hal ini menan- dakan bahwa semakin besar jumlah anggota dewan komisaris akan semakin baik kinerja maqasid syariah bank syariah.

Hasil analisis regresi untuk variabel dewan pengawas syariah (DPS) menunjukkan bahwa jumlah dewan pengawas syariah tidak berpengaruh terhadap kinerja maqasid syariah bank syariah. Hasil ini mengindikasikan bahwa jumlah dewan pengawas yang banyak tidak dapat mendorong kinerja maqasid syariah bank syariah. Hal ini kemungkinan disebabkan karena dari statistik deskriptif, rata-rata jumlah anggota dewan pengawas syariah hanya sebesar 2,48 jauh di bawah ratarata jumlah dewan komisaris yang nilai rataratanya sebesar 4,18. Rata-rata jumlah dewan pengawas syariah yang masih sedikit ini kemungkinan menjadikan peran dewan pengawas syariah yang belum maksimal sehingga belum mampu mendorong kinerja maqasid syariah bank syariah.

Tabel 8: Hasil Analisis Regresi Berganda

\begin{tabular}{lrrrrl}
\hline Keterangan & Prediksi & \multicolumn{1}{c}{ B } & t-statistik & \multicolumn{1}{c}{ Sig-t } & Kesimpulan \\
\hline Constant & & 34,953 & 20,773 &, 000 & \\
KOMIS & - &, 651 & 2,136 &, 041 & Ha1 didukung \\
DPS & - &,- 991 & $-1,503$ &, 143 & Ha2 tidak didukung \\
KOMIT & - & $-1,025$ & $-2,691$ &, 011 & Ha3 tidak didukung \\
Adjusted R Square $=, 163$ & & & & \\
F =3,203 ; sig-F =,037 & & & \\
Sumber : Data diolah $(2015)$ &
\end{tabular}


Menurut Umam (2015), di Indonesia terdapat dewan pengawas syariah yang menjadi dewan pengawas syariah di lembaga keuangan lain serta terdapat dewan pengawas syariah yang menjadi dewan syariah nasional. Adanya beberapa dewan pengawas syariah yang merangkap jabatan sebagai dewan pengawas syariah di lembaga keuangan lain serta menjabat sebagai dewan syariah nasional menandakan bahwa jumlah dewan pengawas syariah di Indonesia masih sedikit. Selain itu, rangkap jabatan tersebut dapat mengurangi tingkat pengawasan yang dilakukan dewan pengawas syariah, sehingga keberadaan dewan pengawas syariah belum mampu mendorong peningkatan kinerja bank syariah.

Pada tingkat signifkansi 5\%, hasil analisis regresi menunjukkan bahwa jumlah anggota komite audit (KOMIT) berpengaruh negatif signifkan terhadap kinerja maqasid syariah bank syariah. Temuan ini menunjukkan bahwa bahwa hipotesis kedua yang menyatakan bahwa jumlah anggota komite audit berpengaruh positif terhadap kinerja maqasid syariah bank syariah tidak didukung. Hasil ini sejalan dengan penelitian Al-Matari, et al. (2012) yang meneliti perusahaan di Arab Saudi. Hal tersebut menandakan bahwa semakin sedikit jumlah anggota komite audit maka kinerja maqasid syariah bank syariah justru akan semakin baik.

Hasil analisis tersebut menunjukkan temuan yang berlawanan antara pengujian hipotesis tentang jumlah anggota dewan komisaris dan jumlah anggota komite audit. Menurut Peraturan Bank Indonesia No.11/33/PBI/209 beberapa hal yang menjadi tugas dan wewenang dewan komisaris antara lain melakukan pengawasan dan memberikan nasihat kepada direksi, memantau dan mengevaluasi pelaksanaan kebijakan strategis bank syariah. Dilihat dari wewenang dan tanggung jawab tersebut dewan komisaris lebih banyak bertugas terkait dengan pembuatan keputusan yang tidak terstruktur (misal keputusan arah rencana strategis bank syariah), sehingga untuk dapat menjalankan tugas tersebut memerlukan lebih banyak jumlah anggota dewan komisaris. Menurut
Muttakin dan Ullah (2012), semakin besar jumlah anggota board akan menyediakan pengetahuan, keahlian, kepakaran dan jaringan profesional dan sosial yang lebih baik, oleh karenanya proses pembuatan keputusan akan menjadi lebih baik. Adanya pengetahuan dan keahlian yang lebih baik juga akan meningkatkan tingkat pengawasan, pembuatan keputusan strategis dan pemberian nasihat dewan komisaris terhadap direksi bank syariah sehingga memeungkinkan penekanan terhadap masalah agensi.

Sementara itu, menurut Peraturan Bank Indonesia No.11/33/PBI/209 komite audit memiliki tugas dan tanggungjawab antara lain melakukan evaluasi pengendalian internal, melakukan koordinasi dengan kantor akuntan publik, melakukan evaluasi pelaksanaan audit internal, melakukan evaluasi pelaksanaan tindak lanjut temuan bank Indonesia, DPS, dan/atau auditor eksternal. Dilihat dari tugas dan tanggung jawabnya, komite audit lebih banyak membuat keputusan yang terstruktur dimana pedoman pembuatan keputusan cukup jelas. Misalkan tugas evaluasi pelaksanaan tindak lanjut temuan DPS, keputusan yang diambil terbatas pada apakah management bank syariah sudah melakukan perbaikan atas temuan DPS atau belum, sehingga dilihat dari tugas dan tanggungjawabnya jumlah anggota komite audit akan lebih baik jika jumlahnya sedikit. Jumlah anggota komite audit yang banyak dapat memungkinkan terciptanya perdebatan yang tidak diperlukan dan penundaan dalam pembuatan keputusan (Ghabayen 2012). Hal ini dapat terjadi karena pembuatan keputusan oleh komte audit lebih pada pembuatan keputusan yang terstruktur sehingga tidak memerlukan banyak sumberdaya manusia yang terlibat di dalamnya.

\section{SIMPULAN}

Tujuan dari penelitian ini adalah untuk menguji secara empiris pengaruh good corporate governance yang diproksikan dengan jumlah anggota dewan komisaris, jumlah dewan pengawas syariah, dan jumlah anggota komite audit terhadap kinerja maqasid syariah bank 
syariah. Berdasarkan hasil pengujian dan pembahasan sebagaimana telah disajikan dalam bagian sebelumnya, maka dapat disimpulkan bahwa jumlah anggota dewan komisaris berpengaruh positif signifikan terhadap kinerja maqasid syariah bank syariah di Indonesia. Hal ini menandakan bahwa semakin besar jumlah dewan komisaris maka kinerja maqasid syariah bank syariah akan menjadi lebih baik.

Pengujian terhadap variabel jumlah anggota komite audit menemukan hasil yang berlawanan dengan hipotesis yang dirumuskan. Hasil pengujian hipotesis kedua menunjukkan bahwa jumlah anggota komite audit justru berpengaruh negatif signifikan terhadap kinerja maqasid syariah bank syariah. Artinya, semakin sedikit jumlah anggota komite audit justru akan dapat meningkatkan kinerja maqasid syariah bank syariah dari pada jumlah komite audit yang besar. Sementara variabel jumlah anggota dewan pengawas syariah tidak berpengaruh signifikan terhadap kinerja maqasid syariah bank syariah.

Hasil penelitian ini diharapkan dapat menjadi masukan bagi bank syariah dalam penentuan jumlah anggota dewan komisaris, jumlah anggota komite audit, dan jumlah anggota dewan pengawas syariah. Perbedaan deskripsi kerja antara dewan komisaris dan komite audit mengakibatkan kebutuhan akan jumlah angggota dewan komisaris dan komite audit menjadi berbeda. Untuk dapat mencapai kinerja maqasid syariah bank syariah yang baik membutuhkan jumlah anggota dewan komisaris yang lebih banyak sementara komite audit akan lebih baik dengan jumlah anggota yang sedikit.

Beberapa keterbatasan dalam penelitian ini antara lain: (1) Jumlah sampel bank yang digunakan hanya 7 bank umum syariah, belum dapat menggunakan 11 bank umum syariah yang sudah ada di Indonesia dan jangka waktu pengambilan sampel relatif pendek hanya 5 tahun dari tahun 2010-2014. Hal ini dikarenakan tidak semua bank syariah di Indonesia menyajikan laporan keuangan di website bank syariah secara rutin. Penelitian selanjutnya hendaknya dapat menambah sam- pel dengan menambahkan sampel bank syariah dari negara lain. (2) Pengukuran kinerja yang digunakan belum dapat memberikan pedoman tingkatan baik dan buruk kinerja maqasid syariah bank syariah. Perlu dikembangkan lebih lanjut mengenai pengukuran kinerja maqasid syariah yang lebih baik. Hal yang perlu dikembangkan adalah kisaran angka kinerja maqasid syariah yang menunjukkan suatu bank telah mencapai maqasid syariah yang sangat baik, baik, cukup baik, sedang dan buruk.

\section{DAFTAR REFERENSI}

Adams, R. B, dan H. Mehran. 2012. Bank board structure and performance: Evidence for large bank holding companies. Journal Finance Intermediation 21 (2): 243-267.

At Baidhani, A. M. 2013. The Effect of corporate governance on bank performance. Cairo: German University in Cairo.

At Matari, Y. A., A. K. Al-Swidi, F. H. Fadzil dan E. M. At Matari. 2012. Board of directors, audit committee chrarteristics and performance of saudi arabia listed companies. International Review of Management and Marketing 2 (4): 241-251.

Bank Indonesia, Peraturan Bank Indonesia No.11/33/PBI/2009

Bouaziz, Z. 2012. The Impact of presence audit committees on the financial performance of Tunisians companies. International Journal of Management and Business Studies 2 (4): 57-64.

Faozan, A. 2013. Implementasi good corporate governance dan peran dewan pengawas syariah di bank syariah. Jurnal Ekonomi Islam 7 (1): 1-14.

Ghabayen, M. A. 2012. Board characteristics and firm performance: Case of Saudi Arabia. International Journal of Accounting and Financial Reporting 2 (2): 168-200. 
Hoque, M. Z., M. R. Islam, dan H. Ahmed. 2012. Corporate governance and bank performance: case in Bangladesh. Available from: Social Science Research Network http://papers.ssrn.com/sol3/papers.cfm ?abstract_id=2208903, 1-37.

James, B. J, dan C. Joseph. 2015. Corporate governance mechanisms and bank performance: Resource based view. International Accounting and Business Conference 2015, IABC 2015: 117 124.

Jensen, M. C, dan W. H. Meckling. 1976. Theory of the firm: Managerial behaviour, agency cost and ownership sturcture. Journal of Finanacial Economics 3 (4): 305-360.

Lehn, K., S. Patro, dan M. Zhao. 2004. Determinants of the size and structure of corporate board 1935-2000. (Working Paper) Pitsburgh: Katz Graduate School of Business, University of Pitsburgh.

Mohammed, M. O., A. D. Razak, dan F. M. Taib. 2008. The Performance of islamic banking based on the maqasid syariah. IIUM International Accounting Conference (INTAC IV): 1-17.

Mollah, S, dan M. Zaman. 2015. Shariah Supervision, corporate governance, and performance: Conventional vs islamic banks. Journal of Banking and Finance 58: 418-435.

Muttakin, M. B, dan M. S. Ullah. 2012. Corporate governance and bank perfomance: Evidence from Bangladesh. Corporate Board: Role, Duties \& Composition 8 (1): 62-68.
Reni, D., Muklis, dan A. Cholisni. 2014. Impact of the perception of islamic bank management on islamic bank objective to the social and economic performance using maqasid al-sharia approach. Proceedings of Developing A Framework for Maqasid Al-ShariaBased Index Of Socio Economic, 415474.

Rouse, P, dan M. Putterill. 2003. An integral framework for performance measurement. Management Decision 41 (8): 791-805.

Sam'ani. 2008. Pengaruh good corporate governance dan leverage terhadap kinerja keuangan pada perbankan yang terdaftar di Bursa Efek Indonesia tahun 2004 - 2007. Semarang: Universitas Diponegoro.

Syam, D, dan T. Najda. 2012. Analisis kualitas penerapan good corporate governance pada bank umum syariah di Indonesia serta pengaruhnya terhadap terhadap tingkat pengembalian dan resiko pembiayaan. Jurnal Reviu Akuntansi Keuangan 2 (1): 195-206.

Umam, K. 2015. Urgensi standarisasi dewan pengawas syariah dalam meningkatkan kualitas audit kepatuhan syariah. Jurnal Perhimpunan Mahasiswa Hukum Indonesia 1 (2): 114-138.

Republik Indonesia. 2007. Undang-undang No.40 tahun 2007 tentang perseroan terbatas. Jakarta.

Zahrah, M. A. 1994. Ushul Fiqih. Jakarta: PT Pustaka Firdaus. 